Journal of Advanced Research in Fluid Mechanics and Thermal Sciences

\title{
Numerical Investigation to Asses and Optimize Performance of Flat Plate Solar Collector by Using Different Working Fluid
}

\author{
Yussra Malalah Abdula ${ }^{1, *}$, Gadeer Salim ${ }^{1}$, Salman $K^{2}$ \\ Physics Department, College of Science, Mosul University, Mosul, Iraq \\ 2 Department of Mechanical Technical/Production, Al-Kut Technical Institution, Middle Technical University, Baghdad, Iraq
}

\section{ARTICLE INFO ABSTRACT}

\section{Article history:}

Received 22 January 2021

Received in revised form 15 July 2021

Accepted 20 July 2021

Available online 17 September 2021

Keywords:

Flat plate solar collector; CFD; thermal efficiency; solar water heater; nanofluid of $\mathrm{Cu} /$ water heater

\begin{abstract}
Sustainable energy becomes an optimal alternative to overcome environmental pollution economical cost of fossil fuel. One of the most effective means to invest solar radiation is flat plate solar collectors. A study carried out to optimize and assess the performance of flat plate solar collector (FPSC) for domestic and industrial applications in the Iraq climate. A 3D numerical model of FPSC has modeled by ANSYS19, CFD tool has been used to investigate thermal transfer through FPSC based on different working fluid. Water, and nanofluid of water/copper nanomaterials were used as working fluid with three different concentrations levels, $0.011 \%, 0.055 \%$, and $0,101 \%$. The velocity of water was 0.3 , and $0.5 \mathrm{~m} / \mathrm{sec}$ respectively. The result of the numerical model was compared with a literature study to prove the reliability of the current model. The result of the current study indicated that, adding Cu nanoparticular to the working fluid enhanced temperatures outlet of FPSC. Also, maximum temperatures can be achieved by reducing the velocity value.
\end{abstract}

\section{Introduction}

Increasing demand for energy produced negative environmental impact as a result of fossil fuel usage. The researchers did great efforts to enhance alternatives' performance of natural energy devices [1]. Resources of natural energy such as hydropower, solar energy, and wind energy are available for human whole time. Solar energy is used to supply hot water for domestic, and industrial applications [2]. Flat Plate Solar Collectors (FPSCs) is considered a simple device and used widely as space heating, domestic application, and industrial application. It consists of absorber, glass cover, pipes, box, insulator, storage unit. The working principle depends on solar radiation received by the absorber plate, then transfers the thermal heat to the working fluid which passes through the collector tubes. The working fluid is circulation inside pipes hence, its temperature increases due exposure time for sunlight. performance of FPSCs depends on absorber geometry, area, volume, the surrounding temperature, pipe diameter, number of pipes in the box, and tilt angle $[3,4]$. It can be classified according to working fluid type that passage in the pipe. Air solar heater when working fluid

\footnotetext{
* Corresponding author.

E-mail address: yussra_aphy@yahoo.com
}

https://doi.org/10.37934/arfmts.87.2.4455 
used is air, while the liquid solar heater is used water, and colloidal(nanofluid) as working fluid water is used [5]. The stability of nanofluid along with time is one of most characters that must be investigated to achieve the purpose. It has significant findings to used which certain costs of construction, installation, and maintenance. However, it has benefits associated with the cost such as environmental impact, and saving fuel [6]. In the last few years is widely used suspensions colloidal "nanofluid" as a working fluid instead of liquid to enhance efficiency and performance of solar energy systems such as FPSCs [7-11]. It has better thermal properties than liquid [12,13]. It is preparing by adding nanoparticular materials that range $0<100 \mathrm{~nm}$ to liquid (water, oil, or ethylene glycol with limited volume fraction values to avoid problem might be happened such as flow blockage, sedimentation, and agglomeration [10,14,15]. Synthesis a colloidal suspension is not a simple issue, therefore many studies recommended some important consideration must be taken into account [16]. The stability of nanofluid along with time is one of most characters that must be investigated to achieve the purpose. It is might be enhanced by adding a surfactant, which is an economical and efficient method [17-21]. Numerous studies were conducted to prepared various nanofluid suspension for enhancing thermal properties such as, yAl2O3, Al2O3 /water [8, 22-24], $\mathrm{CuO}, \mathrm{SiO} 2$ /water [25, 26, 27], CuO/ethylene glycol [28], Cu/water[29], Ag/water[29-32], Ag/ethylene glycol, [33] ZnO/water [33], ZnO/ethylene glycol [34, 35], MWCNTs/water [36].

In this study, a Flat Plate Solar Collector is modeled by using DesignModeler19 and analyzed by Fluent CFD tool to observe the performance of FPSC based on different working fluid. The study area is Al- Kut city, Wassit, Iraq, on 1st October during the daily time between 9 Am to 4 Pm. During October month the weather temperature is reduced, therefore performance of solar collector diverged. The study aim is assessment performance of FPSC by using water as working fluid, also, to enhance temperature outlet as well as, the performance by using $\mathrm{Cu} / \mathrm{H}_{2} \mathrm{O}$ nanofluid as working fluid.

\section{Method and Theory}

\subsection{Energy Analysis}

FPSCs performance is calculated by an energy balance during steady state operation based on the developed mathematical model conducted ASHRE. Therefore, Calculating of heat gain by the solar collector can be expressed by Eq. (1) [11, 37]

$Q_{g}=\dot{m} \cdot c_{p \cdot}\left(T_{o}-T_{i}\right)=\left[A \cdot H_{R} \cdot S \cdot(\alpha \tau)\right]-\left[A \cdot H_{R} \cdot Q_{L} \cdot\left(T_{o}-T_{a}\right]\right.$

where $Q_{g}$ is heat gain by absorber w, $\dot{m}$ mass flow rate of fluid, $\mathrm{Kg} / \mathrm{sec} . \mathrm{c}_{p}$ is specific heat capacity of fluid $\mathrm{Kj} / \mathrm{Kg} . \mathrm{K} . \mathrm{T}_{o}, T_{i}$ are represents fluid temperature inlet, and fluid temperature outlet, $\mathrm{K} . \mathrm{H}_{\mathrm{R}}$ is heat removal factor. $\mathrm{S}$ is solar intensity, $\frac{W}{\mathrm{~m}^{2}} . \alpha, \tau$ are absorptance, transmission for plate, and glass cover respectively. $\mathrm{Q}_{\mathrm{L}}$ is overall heat losses coefficient $W / m^{2} . K$.

\subsection{Specific Heat of Nanofluid}

Specific heat capacity of nanofluid can be calculated by Eq. (2) [38].

$C_{p, c}=C_{p, p} \vartheta+C_{p, b}(1-\vartheta)$

where $C_{p, n}$ is specific heat of suspension colloidal, $C_{p, p}$ is specific heat of nanoparticular, $C_{p, b}$ is specific heat of base fluid, $K j / K g . K, \vartheta$ is dimensionless concentration ratio of nanoparticular. 


\subsection{Concentrations of Nanofluid}

Nanoparticular weight concentration of nanofluid is determined by using the following formula in Eq. (3) [39]

$\vartheta=\frac{1}{1+\left[\frac{1-w}{w}\right] \cdot \frac{\rho_{p}}{\rho_{b}}}$

where $w$ is nanoparticular weight concentration, $\rho_{p}, \rho_{b}$ are density of nanoparticular and base fluid respectively, $\frac{\mathrm{Kg}}{\mathrm{m}^{3}}$.

\subsection{Density of Nanofluid}

Density of nanofluid is calculated by suggested formula for theoretical calculation as in Eq. (4) [40]

$\rho_{n}=\rho_{b} \cdot(1-\vartheta)+\rho_{p} \cdot \vartheta$

\subsection{Thermal Conductivity of Nanofluid}

Thermal conductivity of nanofluid is influenced by the concentrations ratio of nanofluid and temperatures [41]. Therefore, experimental works were conducted to observed the influenced and suggested correlations. Thermal conductivity of nanofluid for three concentration levels are evaluated by correlations in formula Eq. (5)-(7) [42-48-49]

$C_{n}=0.4451+0.0519 \ln T ;$ at $\vartheta=0.011 \%$

$C_{n}=0.4633+0.0529 \ln T ;$ at $\vartheta=0.055 \%$

$C_{n}=0.5017+0.0511 \ln T ;$ at $\vartheta=0.101 \%$

where $\mathrm{T}$ is temperature range between $20-60^{\circ} \mathrm{C}$.

\subsection{Viscosity of Nanofluid}

Viscosity of nanofluid sensitive to temperature, and concentration value of nanofluid. Viscosity defines as the resistance of fluid against share force, therefore adding solid nanoparticular concentrations enhanced the resistance and increased viscosity. Growing temperature level is lead to decrease viscosity of nanofluid [39-45-50]. Viscosity of nanofluid can be calculated by Eq. (8)

$\mu_{n}=\mu_{b}(1+\vartheta)$

\subsection{Collector Efficiency}

Solar collector efficiency is evaluated by Eq. (9) [43]

$\eta=\frac{\text { Actual Useful energy }}{\text { Area of collector } \times \text { Solar incidant }}=\frac{Q_{g}}{A \times S}$ 
where $\mathrm{A}$ is solar collector area, $m^{2}$.

\subsection{Numerical Modeling}

The physical model is simulated as a 3D model by ANSYS 19.0 as shown in Figure 1 . Solar collector dimensions and details are included in Table 1. Simulation is performed in weather location of Al-Kut city, Wasit, Iraq Latitude $32.514 \mathrm{~N}$, and longitude $45.823 \mathrm{E}$, on 1st October from $9 \mathrm{Am}$ to $4 \mathrm{Pm}$. Thermophysical properties of materials are presented in Table 2. A modeling and numerical analysis procedures described in Figure 2. Table 3 shows the experimental design of the model using CFD tool. The analysis of solar radiation load has been calculated under some important hypothesis and simplifications as following

- In the solver setting, the effect of gravity was considered.

- Viscosity $(K-\varepsilon)$, Energy, and radiation models were activated.

- Rosseland model was selected to implement calculations of the solar load. It has two advantages, faster and needs less memory capacity also it is recommended when optical thick greater than 3. Location, date, time, mesh directions were defined.

- Materials of solar collector modeled as absorber plate and walls were modeled as aluminum, pipes were copper, the cover of solar was glass, while the fluids were water and nanofluid of $\mathrm{Cu} / \mathrm{H}_{2} \mathrm{O}$.

- All sides were modeled as non-slip surfaces.

- Glass cover modeled as a semi-transparent while, absorber plate considered as opaque.

- Boundary conditions were velocity inlet at the inlet, and the outflow at outlet.

- The data were initialized, and residual calculations were more than $10^{-3}$, as shown in Figure 3.

Table 1

Dimensions of Flat plate solar collector

\begin{tabular}{ll}
\hline Parameters & Dimensions, $\mathrm{mm}$ \\
\hline Box Length & 1100 \\
Box Width & 1000 \\
Box Height & 100 \\
Tube Length & 9900 \\
Tube Diameter & 20 \\
Tube Offset & 100 \\
Tube Thickness & 1 \\
Side Wall Thickness & 1 \\
Upper Cover Thickness (Glass) & 4 \\
Lower Plate Thickness (Absorber) & 1 \\
\hline
\end{tabular}




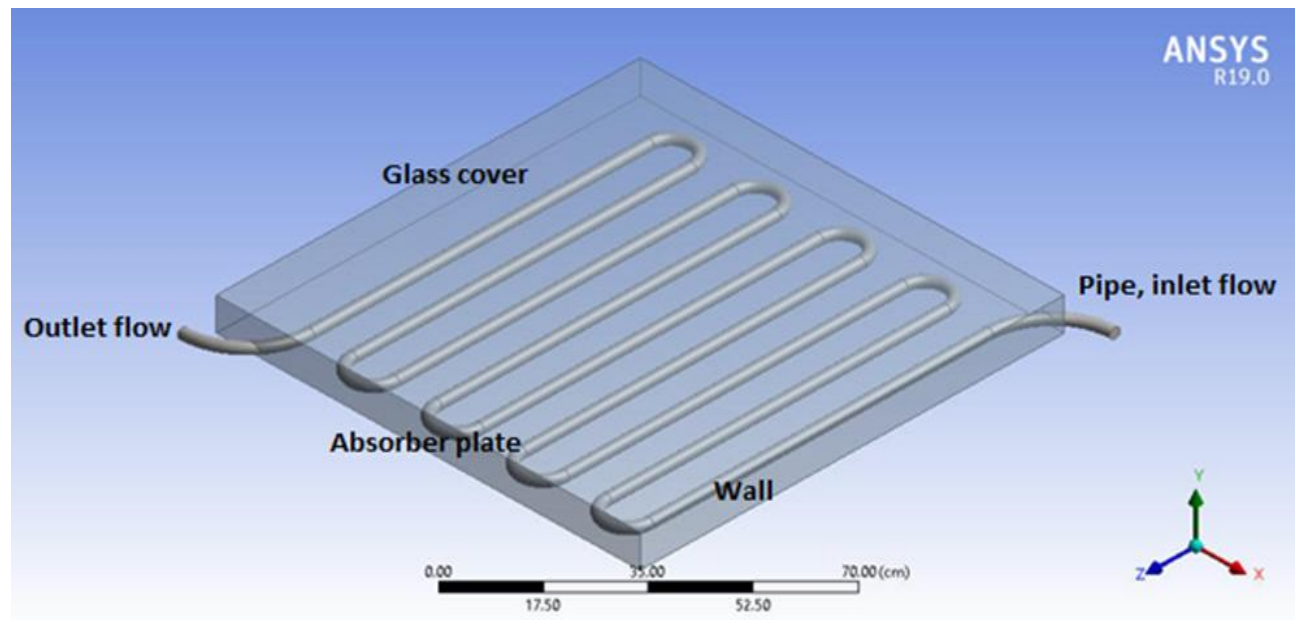

Fig. 1. A scheme of flat plate solar collector

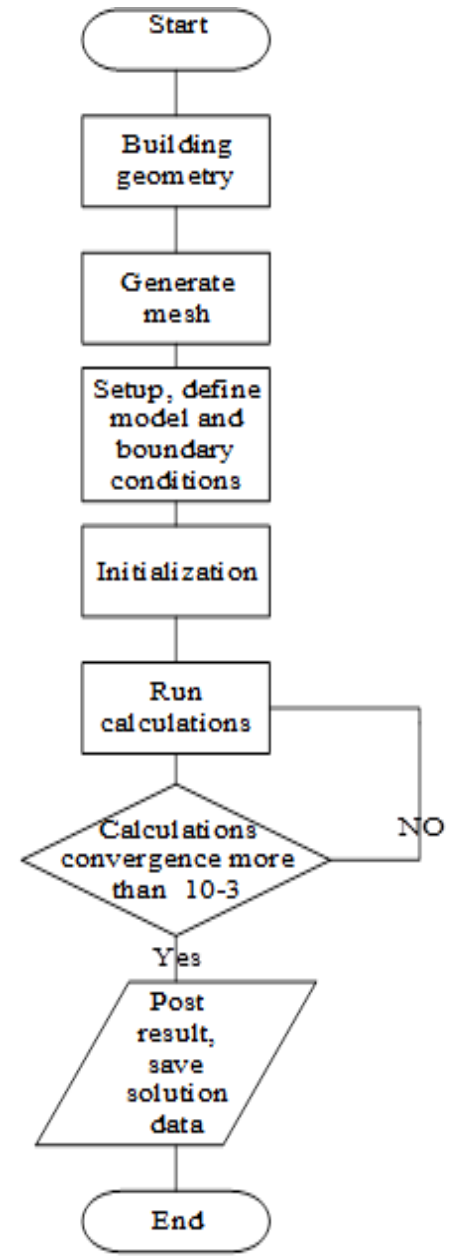

Fig. 2. A computational fluid dynamic flowchart 


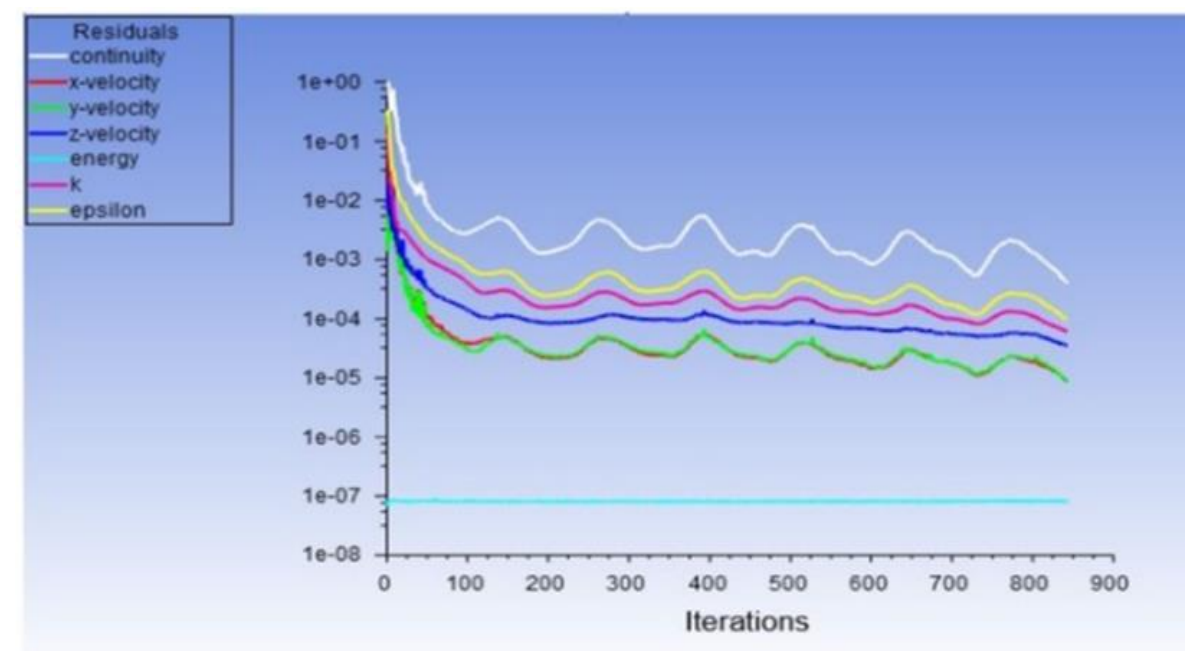

Fig. 3. CFD calculations convergences

Table 2

Thermo-physical properties of materials [44]

\begin{tabular}{lllll}
\hline & Aluminum & Copper & Water & Glass \\
\hline Density $\left(\mathrm{kg} / \mathrm{m}^{3}\right)$ & 2770 & 8800 & 998.2 & 2500 \\
Specific Heat $(\mathrm{J} / \mathrm{kg} . \mathrm{K})$ & 875 & 420 & 4182 & 840 \\
Thermal Conductivity(W/m.K) & 177 & 401 & 0.6 & 1.7 \\
Emissivity & 0.9 & 0.9 & - & \\
\hline
\end{tabular}

Table 3

Design of experimental by using CFD tool

\begin{tabular}{llll}
\hline Case No. & Working fluid & Concentration ratio & Velocity m/sec \\
\hline 1 & Water & -- & 0.3 \\
2 & Water & - & 0.5 \\
3 & $\mathrm{Cu} / \mathrm{H}_{2} \mathrm{O}$ & 0.011 & 0.3 \\
4 & $\mathrm{Cu} / \mathrm{H}_{2} \mathrm{O}$ & 0.055 & 0.3 \\
5 & $\mathrm{Cu} / \mathrm{H}_{2} \mathrm{O}$ & 0.101 & 0.3 \\
6 & $\mathrm{Cu} / \mathrm{H}_{2} \mathrm{O}$ & 0.011 & 0.5 \\
7 & $\mathrm{Cu} / \mathrm{H}_{2} \mathrm{O}$ & 0.055 & 0.5 \\
8 & $\mathrm{Cu} / \mathrm{H}_{2} \mathrm{O}$ & 0.101 & 0.5 \\
\hline
\end{tabular}

\section{Result and Discussion}

\subsection{Validation}

In order to prove the validity of the suggested model under the hypothesis and considerations, the result of the current model compared with a literature study which was calculated based on an experimental study $[43,46,47]$. The present numerical results have been validated with experiments accordingly. Offset values were $5 \%$, and $7 \%$ for maximum temperature at volume flow rates 5.1 and $6.31 \mathrm{~L} / \mathrm{min}$ respectively.

\subsection{Results}

Solar radiation during $1^{\text {st }}$ October and temperature distribution on the solar collector are presented in Figure 4(a) and (b). It can be noticed from the figure, maximum solar radiation reached $942.580 \mathrm{~W} / \mathrm{m}^{2}$ in the mid-day at 12:00 O'clock. Also, solar radiation incident in the afternoon decreasing rapidly more than the growth in the morning. The velocity of liquid was 0.3, and $0.5 \mathrm{~m} /$ 
sec respectively with three nanoparticular concentration values $\vartheta=0.011 \%, 0.055 \%, 0.101 \%$. The maximum recorded temperature was $45.8^{\circ} \mathrm{C}$ at $12: 00$ O'clock when working fluid water and velocity $0.3 \mathrm{~m} / \mathrm{sec}$, while was $44.1{ }^{\circ} \mathrm{C}$ when velocity $0.5 \mathrm{~m} / \mathrm{sec}$, Figure $5(\mathrm{a})$ and (b). Adding nanoparticular material of copper enhanced outlet temperature of working fluid as well as solar collector efficiency. Maximum recorded temperature proportional to nanoparticular concentration value and inversely with velocity. Therefore, at concentration value (C1) $0.011 \%$, and velocity (V1) $0.3 \mathrm{~m} / \mathrm{sec}$, it was 46.5 ${ }^{\circ} \mathrm{C}$ while at concentration (C1) and velocity (V2) $0.5 \mathrm{~m} / \mathrm{sec}$ was $44.4^{\circ} \mathrm{C}$ Figure $6(\mathrm{a})$ and (b).

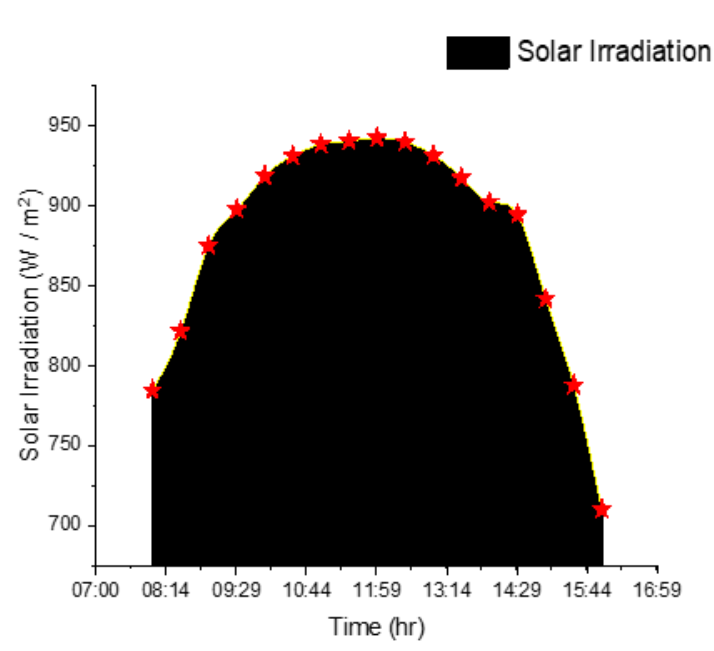

(a)

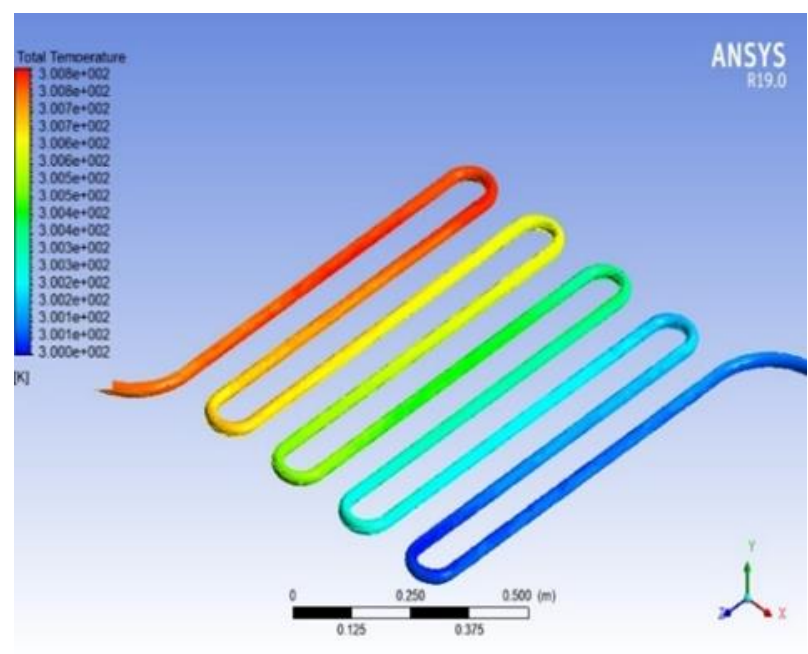

(b)

Fig. 4. (a) Solar radiation incident during 1st October, (b) temperature distribution along the pipe

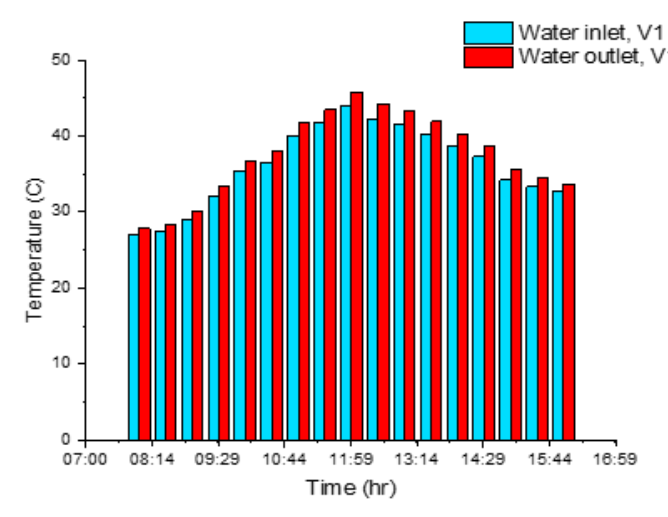

(a)

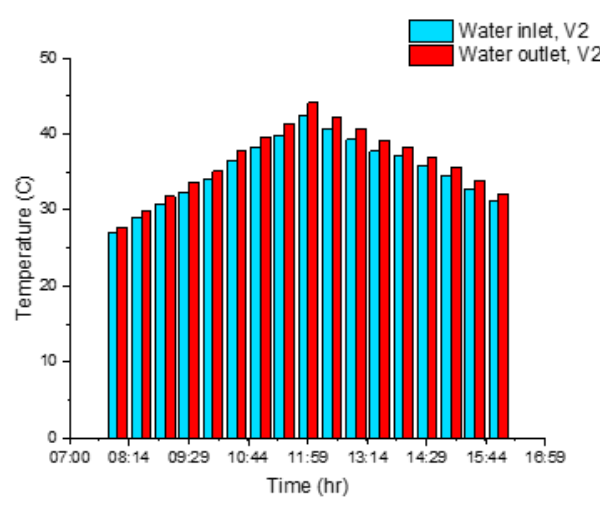

(b)

Fig. 5. Water temperature during exposure daily time at (a) $V_{1}=0.3 \mathrm{~m} / \mathrm{sec}$ (b) $V_{2}=0.5 \mathrm{~m} / \mathrm{sec}$ 


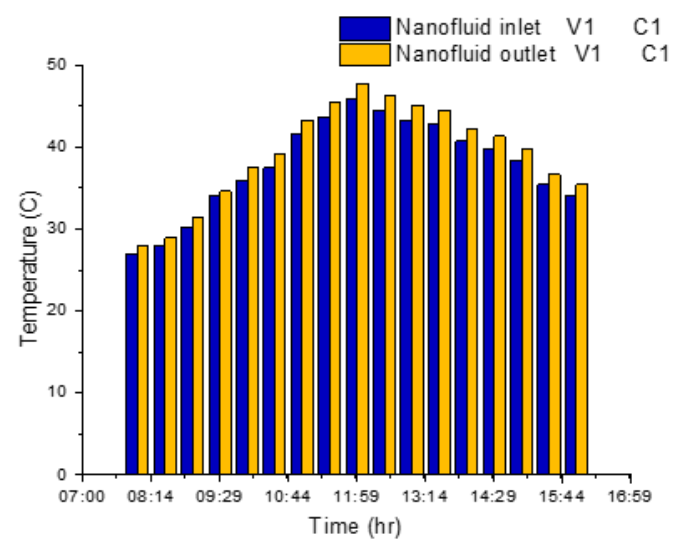

(a)

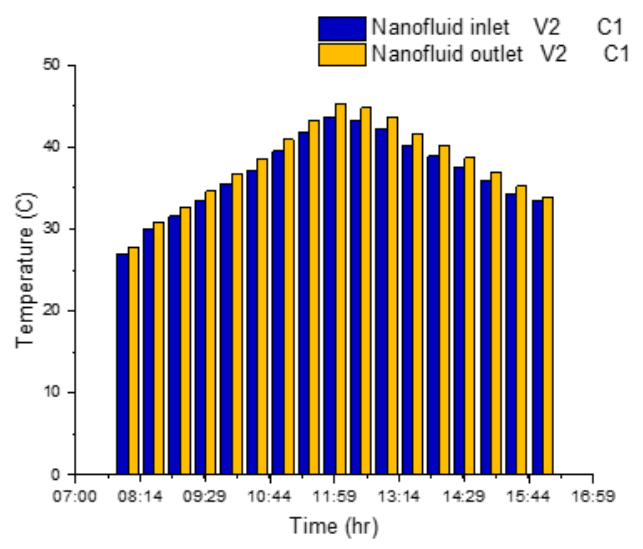

(b)

Fig. 6. Nanofluid temperature at nanoparticular concentration $\vartheta=0.011 \%$ (a) velocity $\mathrm{V}_{1}=$ $0.3 \mathrm{~m} / \mathrm{sec}$ (b) velocity $\mathrm{V}_{2}=0.5 \mathrm{~m} / \mathrm{sec}$

A second concentration the working fluid temperature increased slightly, the maximum temperature at concentration value $0.055 \%$, and velocity $0.3 \mathrm{~m} / \mathrm{sec}$ was $46.7^{\circ} \mathrm{C}$, while was $44.5^{\circ} \mathrm{C}$, as shown in Figure 7(a) and (b).

In the third concentration level $(0,101 \%)$ nanoparticular concentration doubled to observe its effects on temperature, as well as solar collector efficiency. Increasing temperature was clear, therefore the maximum recorded temperature was 47.2 , and $44.9{ }^{\circ} \mathrm{C}$ at 0.3 , and $0.5 \mathrm{~m} / \mathrm{sec}$ respectively, included in Figure 8(a) and (b).

The maximum observed thermal efficiency of FPSC was $61 \%$ when water is used as working fluid with velocity $0.3 \mathrm{~m} / \mathrm{sec}$, while it was $54 \%$ when velocity $0.5 \mathrm{~m} / \mathrm{sec}$, Figure $9(\mathrm{a})$ and (b).

Maximum thermal efficiency was $64 \%, 67 \%, 74 \%$ under conditions of $0.011,0.055,0.101 \%$ nanoparticular concentrations respectively, and velocity $0.3 \mathrm{~m} / \mathrm{sec}$. Whereas, it was 55\%, 57\%, 59\% under conditions of $0.011,0.055,0.101 \%$ nanoparticular concentrations respectively, and velocity $0.5 \mathrm{~m} / \mathrm{sec}$.

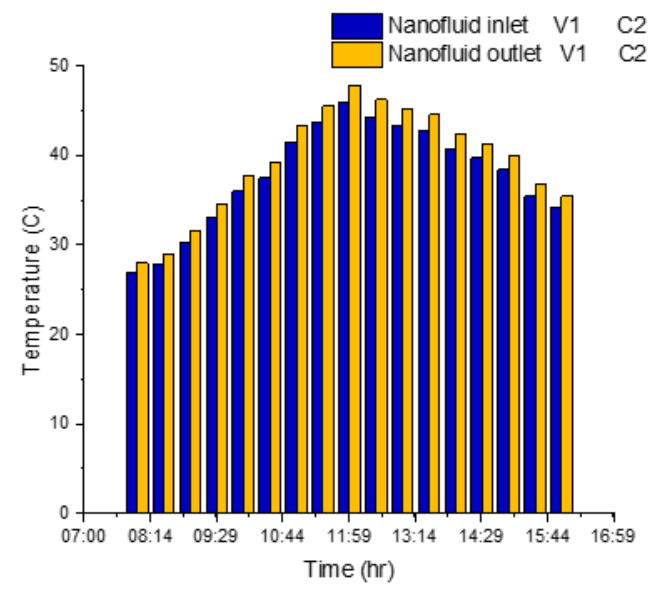

(a)

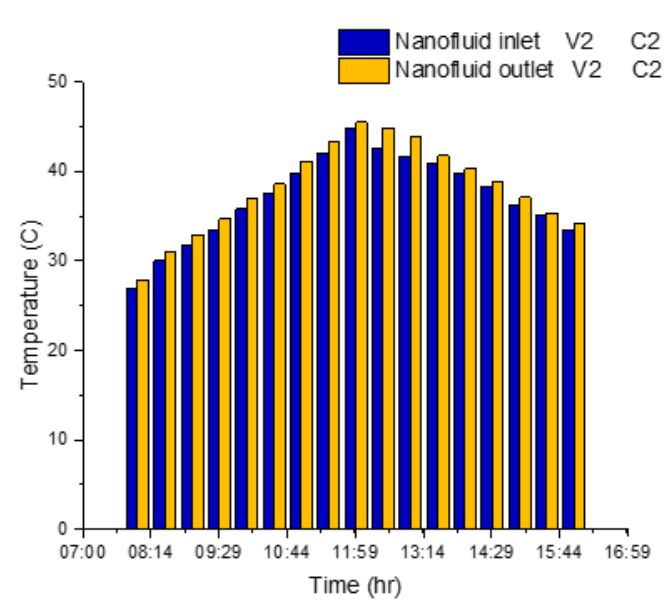

(b)

Fig. 7. Nanofluid temperature at nanoparticular concentration $\vartheta=0.055 \%$ (a) velocity $\mathrm{V}_{1}=$ $0.3 \mathrm{~m} / \mathrm{sec}$ (b) velocity $\mathrm{V}_{2}=0.5 \mathrm{~m} / \mathrm{sec}$ 


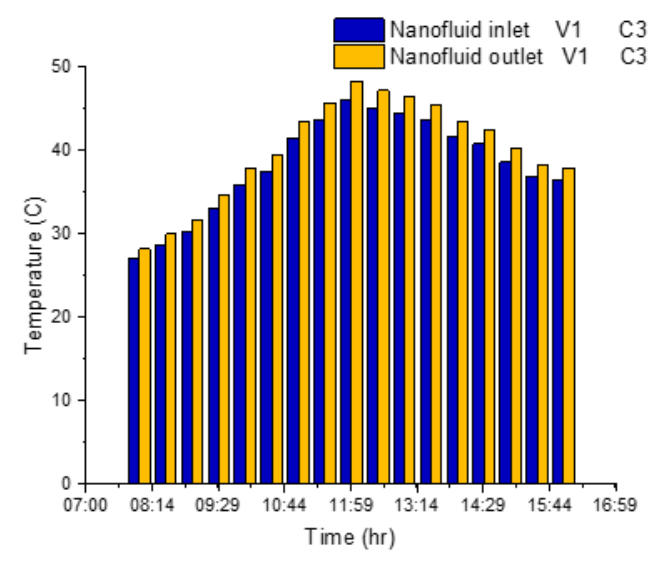

(a)

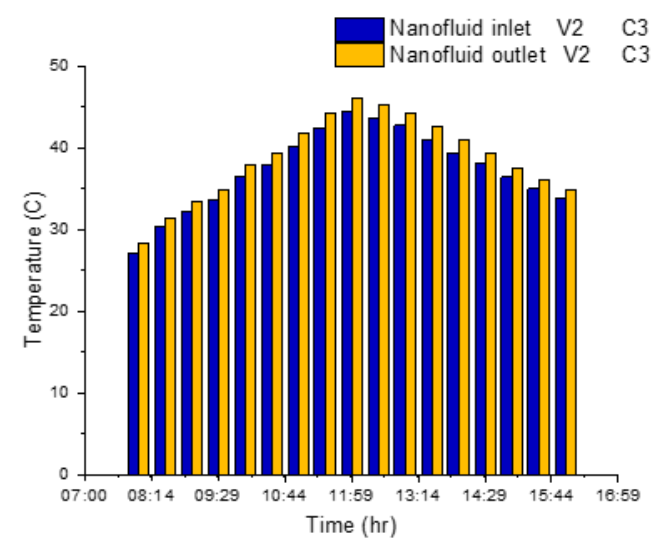

(b)

Fig. 8. Nanofluid temperature at nanoparticular concentration $\vartheta=0.101 \%$ (a) velocity $\mathrm{V}_{1}=$ $0.3 \mathrm{~m} / \mathrm{sec}$ (b) velocity $\mathrm{V}_{2}=0.5 \mathrm{~m} / \mathrm{sec}$

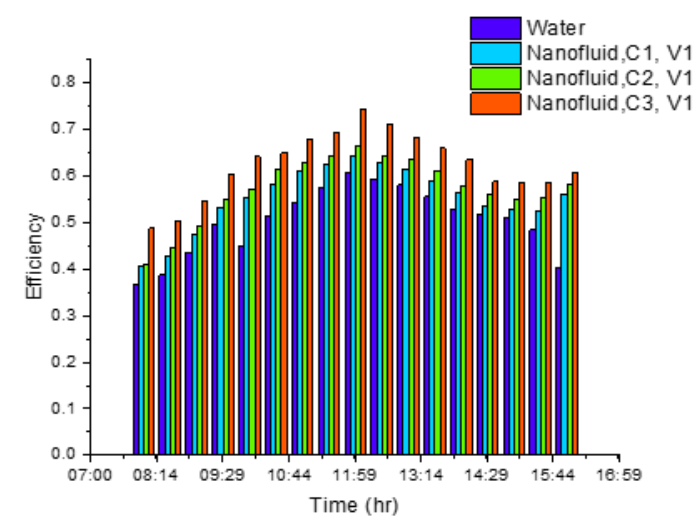

(a)

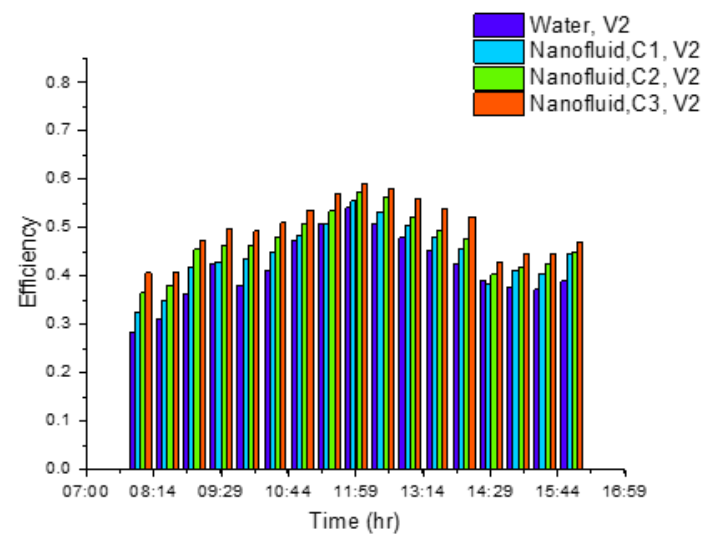

(b)

Fig. 9. Thermal efficiency of FPSC (a) at flow velocity $0.3 \mathrm{~m} / \mathrm{sec}(\mathrm{b})$ at flow velocity $0.5 \mathrm{~m} / \mathrm{sec}$

\section{Conclusions}

A numerical investigation carried out to clarify the ability and efficiency of FPSCs for domestic industrial applications when working fluid be water or nanofluid of $\mathrm{Cu} / \mathrm{H}_{2} \mathrm{O}$ in Al-Kut city, Iraq. According to the result of numerical simulation can be concluded that

i. FPSCs can provide domestic application by temperature range about 27 to 45.8 , and about $47.2{ }^{\circ} \mathrm{C}$ for water and nanofluid respectively.

ii. Increasing nanoparticular volume concentrations increased absorptances of working fluid for solar radiation which lead to increase temperatures, as well as efficiency of solar collector.

iii. Low velocity allows to increase exposure time of working fluid to solar radiation which result in increased temperature outlet and efficiency.

iv. In the study used a concentration levels to avoid the problem might be happened in real design such as flow blockage, sedimentation, and agglomeration.

v. In applications which required higher temperatures, it can be achieved by increasing pipes length.

vi. Cu nanoparticular expensive somewhat, therefore adding nanoparticular must consider its advantage relative to cost. 


\section{Acknowledgment}

The authors thankful Kut Technical Institute_ Middle Technical University for their support.

\section{Conflict}

The authors confirm that the work not submitted to another journal or conflicted from other works.

\section{References}

[1] Finance, Bloomberg New Energy. "Global trends in renewable energy investment 2017." (2017).

[2] Jowzi, Mohammad, Farzad Veysi, and Gholamabbas Sadeghi. "Experimental and numerical investigations on the thermal performance of a modified evacuated tube solar collector: Effect of the bypass tube." Solar Energy 183 (2019): 725-737. https://doi.org/10.1016/i.solener.2019.03.063

[3] Farhana, K., K. Kadirgama, M. M. Rahman, D. Ramasamy, M. M. Noor, G. Najafi, M. Samykano, and A. S. F. Mahamude. "Improvement in the performance of solar collectors with nanofluids-A state-of-the-art review." Nano-Structures \& Nano-Objects 18 (2019): 100276. https://doi.org/10.1016/j.nanoso.2019.100276

[4] Kundu, Balaram. "Performance analysis and optimization of absorber plates of different geometry for a flat-plate solar collector: a comparative study." Applied thermal engineering 22, no. 9 (2002): 999-1012. https://doi.org/10.1016/S1359-4311(01)00127-2

[5] Pang, Wei, Yanan Cui, Qian Zhang, Gregory J. Wilson, and Hui Yan. "A comparative analysis on performances of flat plate photovoltaic/thermal collectors in view of operating media, structural designs, and climate conditions." Renewable and Sustainable Energy Reviews $119 \quad$ (2020): 109599. https://doi.org/10.1016/i.rser.2019.109599

[6] Sharaf, Hussein Kadhim, M. R. Ishak, S. M. Sapuan, N. Yidris, and Arash Fattahi. "Experimental and numerical investigation of the mechanical behavior of full-scale wooden cross arm in the transmission towers in terms of loaddeflection test." Journal of Materials Research and Technology 9, no. 4 (2020): 7937-7946. https://doi.org/10.1016/i.jmrt.2020.04.069

[7] Acaroğlu, Hakan, and M. Celalettin Baykul. "Economic guideline about financial utilization of flat-plate solar collectors (FPSCs) for the consumer segment in the city of Eskisehir." Renewable and Sustainable Energy Reviews 81 (2018): 2045-2058. https://doi.org/10.1016/i.rser.2017.05.291

[8] Elsheikh, A. H., S. W. Sharshir, Mohamed E. Mostafa, F. A. Essa, and Mohamed Kamal Ahmed Ali. "Applications of nanofluids in solar energy: a review of recent advances." Renewable and Sustainable Energy Reviews 82 (2018): 3483-3502. https://doi.org/10.1016/i.rser.2017.10.108

[9] Genc, Alper Mete, Mehmet Akif Ezan, and Alpaslan Turgut. "Thermal performance of a nanofluid-based flat plate solar collector: A transient numerical study." Applied Thermal Engineering 130 (2018): $395-407$. https://doi.org/10.1016/i.applthermaleng.2017.10.166

[10] Verma, Sujit Kumar, and Arun Kumar Tiwari. "Application of $\mathrm{Ag} / \mathrm{H}_{2} \mathrm{O}$ nanofluid in flat plate solar collector (FPSC) for heat transport performance analysis." In Proceedings of the 25th National and 3rd International ISHMT-ASTFE Heat and Mass Transfer Conference (IHMTC-2019). Begel House Inc., 2019. https://doi.org/10.1615/IHMTC-2019.610

[11] Sharaf, Hussein Kadhim, M. R. Ishak, S. M. Sapuan, and N. Yidris. "Conceptual design of the cross-arm for the application in the transmission towers by using TRIZ-morphological chart-ANP methods." Journal of Materials Research and Technology 9, no. 4 (2020): 9182-9188. https://doi.org/10.1016/i.jmrt.2020.05.129

[12] Hamidi, Saad T. "An Experimental Investigation on Thermal Efficiency of Flat Plate Tube Solar Collector using Nanofluid with Solar Tracking Mechanism." Engineering and Technology Journal 37, no. 11A (2019): 475-487.

[13] Nejad, Marjan B., H. A. Mohammed, O. Sadeghi, and Swar A. Zubeer. "Influence of nanofluids on the efficiency of Flat-Plate Solar Collectors (FPSC)." In E3S Web of Conferences, vol. 22, p. 00123. EDP Sciences, 2017. https://doi.org/10.1051/e3sconf/20172200123

[14] Raheemah, S. H., M. A. Ashham, and K. Salman. "Numerical investigation on enhancement of heat transfer using rod inserts in single pipe heat exchanger." Journal of Mechanical Engineering and Sciences 13, no. 4 (2019): 61126124. https://doi.org/10.15282/jmes.13.4.2019.24.0480

[15] Ziyadanogullari, N. Budak, H. L. Yucel, and C. Yildiz. "Thermal performance enhancement of flat-plate solar collectors by means of three different nanofluids." Thermal Science and Engineering Progress 8 (2018): 55-65. https://doi.org/10.1016/i.tsep.2018.07.005

[16] Raheemah, Saddam Hussein, Kareem Idan Fadheel, Qais Hussein Hassan, Ashham Mohammed Aned, Alaa Abdulazeez Turki Al-Taie, and Hussein Kadhim. "Numerical Analysis of the Crack Inspections Using Hybrid Approach for the Application the Circular Cantilever Rods." Pertanika Journal of Science \& Technology 29, no. 2 (2021). https://doi.org/10.47836/pjst.29.2.22 
[17] Sharaf, Hussein Kadhim, Sadeq Salman, Marwah H. Abdulateef, Rustem R. Magizov, Vasilii Ivanovich Troitskii, Zaid Hameed Mahmoud, Rafis H. Mukhutdinov, and Harsha Mohanty. "Role of initial stored energy on hydrogen microalloying of ZrCoAl (Nb) bulk metallic glasses." Applied Physics A 127, no. 1 (2021): 1-7. https://doi.org/10.1007/s00339-020-04191-0

[18] Yang, Liu, Weikai Ji, Mao Mao, and Jia-nan Huang. "Dynamic stability, sedimentation, and time-dependent heat transfer characteristics of TiO 2 and CNT nanofluids." Journal of Thermal Analysis and Calorimetry (2019): 1-13. https://doi.org/10.1007/s10973-019-09103-w

[19] Colangelo, Gianpiero, Ernani Favale, Arturo De Risi, and Domenico Laforgia. "A new solution for reduced sedimentation flat panel solar thermal collector using nanofluids." Applied Energy 111 (2013): 80-93. https://doi.org/10.1016/i.apenergy.2013.04.069

[20] Hordy, Nathan, Delphine Rabilloud, Jean-Luc Meunier, and Sylvain Coulombe. "High temperature and long-term stability of carbon nanotube nanofluids for direct absorption solar thermal collectors." Solar Energy 105 (2014): 82 90. https://doi.org/10.1016/i.solener.2014.03.013

[21] Afzal, Asif, Ibrahim Nawfal, I. M. Mahbubul, and Sunil Siddalingappa Kumbar. "An overview on the effect of ultrasonication duration on different properties of nanofluids." Journal of Thermal Analysis and Calorimetry 135, no. 1 (2019): 393-418. https://doi.org/10.1007/s10973-018-7144-8

[22] Ouikhalfan, Mohammed, Abdelouhab Labihi, Mohamed Belaqziz, Hassan Chehouani, Brahim Benhamou, Ahmet Sarı, and Ahmed Belfkira. "Stability and thermal conductivity enhancement of aqueous nanofluid based on surfactant-modified $\quad \mathrm{TiO}_{2}$." Journal of Dispersion Science and Technology (2019). https://doi.org/10.1080/01932691.2019.1578665

[23] Mahbubul, I. M., Elif Begum Elcioglu, R. Saidur, and M. A. Amalina. "Optimization of ultrasonication period for better dispersion and stability of $\mathrm{TiO}_{2}$-water nanofluid." Ultrasonics sonochemistry 37 (2017): $360-367$. https://doi.org/10.1016/i.ultsonch.2017.01.024

[24] Asadi, Amin, Farzad Pourfattah, Imre Miklós Szilágyi, Masoud Afrand, Gaweł Żyła, Ho Seon Ahn, Somchai Wongwises, Hoang Minh Nguyen, Ahmad Arabkoohsar, and Omid Mahian. "Effect of sonication characteristics on stability, thermophysical properties, and heat transfer of nanofluids: A comprehensive review." Ultrasonics sonochemistry 58 (2019): 104701. https://doi.org/10.1016/i.ultsonch.2019.104701

[25] Liu, Jiemei, Ning Wang, Yawei Song, and Bin Yang. "Influence of single and multiple coupling factors on the stability of paraffin-based nanofluids." Heat and Mass Transfer 56, no. 2 (2020): 477-488. https://doi.org/10.1007/s00231019-02715-w

[26] Noghrehabadi, Aminreza, and Rashid Pourrajab. "Experimental investigation of forced convective heat transfer

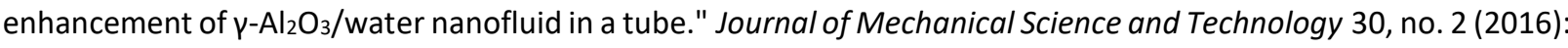
943-952. https://doi.org/10.1007/s12206-016-0148-z

[27] Rao, M. Siva Eswara, Dowluru Sreeramulu, C. J. Rao, and M. V. Ramana. "Experimental investigation on forced convective heat transfer coefficient of a nano fluid." Materials Today: Proceedings 4, no. 8 (2017): 8717-8723. https://doi.org/10.1016/j.matpr.2017.07.220

[28] Khanjari, Y., F. Pourfayaz, and A. B. Kasaeian. "Numerical investigation on using of nanofluid in a water-cooled photovoltaic thermal system." Energy Conversion and Management 122 (2016): $263-278$. https://doi.org/10.1016/j.enconman.2016.05.083

[29] Sheikholeslami, Mohsen. "Numerical investigation for $\mathrm{CuO}-\mathrm{H}_{2} \mathrm{O}$ nanofluid flow in a porous channel with magnetic field using mesoscopic method." Journal of Molecular Liquids 249 (2018): $739-746$. https://doi.org/10.1016/i.molliq.2017.11.069

[30] Alfaryjat, A. A., H. A. Mohammed, Nor Mariah Adam, D. Stanciu, and A. Dobrovicescu. "Numerical investigation of heat transfer enhancement using various nanofluids in hexagonal microchannel heat sink." Thermal Science and Engineering Progress 5 (2018): 252-262. https://doi.org/10.1016/i.tsep.2017.12.003

[31] Said, Zafar, and Rahman Saidur. "Thermophysical properties of metal oxides nanofluids." Nanofluid heat and mass transfer in engineering problems (2017). https://doi.org/10.5772/65610

[32] Agarwal, Ravi, Kamalesh Verma, Narendra Kumar Agrawal, Rajendra Kumar Duchaniya, and Ramvir Singh. "Synthesis, characterization, thermal conductivity and sensitivity of CuO nanofluids." Applied Thermal Engineering 102 (2016): 1024-1036. https://doi.org/10.1016/j.applthermaleng.2016.04.051

[33] Aramesh, Mohamad, Fathollah Pourfayaz, and Alibakhsh Kasaeian. "Numerical investigation of the nanofluid effects on the heat extraction process of solar ponds in the transient step." Solar Energy 157 (2017): 869-879. https://doi.org/10.1016/i.solener.2017.09.011

[34] Vajravelu, K., K. V. Prasad, Jinho Lee, Changhoon Lee, I. Pop, and Robert A. Van Gorder. "Convective heat transfer in the flow of viscous $\mathrm{Ag}$-water and $\mathrm{Cu}$-water nanofluids over a stretching surface." International Journal of Thermal Sciences 50, no. 5 (2011): 843-851. https://doi.org/10.1016/j.ijthermalsci.2011.01.008 
[35] Vajravelu, Kuppalapalle, Kerehalli Vinayaka Prasad, and Chiu-On Ng. "The effect of variable viscosity on the flow and heat transfer of a viscous Ag-water and Cu-water nanofluids." Journal of Hydrodynamics 25, no. 1 (2013): 1-9. https://doi.org/10.1016/S1001-6058(13)60332-7

[36] Hayat, Tasawar, Sumaira Qayyum, Maria Imtiaz, and Ahmed Alsaedi. "Comparative study of silver and copper water nanofluids with mixed convection and nonlinear thermal radiation." International Journal of Heat and Mass Transfer 102 (2016): 723-732. https://doi.org/10.1016/j.ijheatmasstransfer.2016.06.059

[37] Esfahani, Navid Nasajpour, Davood Toghraie, and Masoud Afrand. "A new correlation for predicting the thermal conductivity of $\mathrm{ZnO}-\mathrm{Ag}(50 \%-50 \%) /$ water hybrid nanofluid: an experimental study." Powder Technology 323 (2018): 367-373. https://doi.org/10.1016/j.powtec.2017.10.025

[38] Suganthi, K. S., V. Leela Vinodhan, and K. S. Rajan. "Heat transfer performance and transport properties of ZnOethylene glycol and ZnO-ethylene glycol-water nanofluid coolants." Applied energy 135 (2014): 548-559. https://doi.org/10.1016/i.apenergy.2014.09.023

[39] Li, Yanjun, José Fernández-Seara, Kai Du, Ángel Álvarez Pardiñas, Luis Lugo Latas, and Weixue Jiang. "Experimental investigation on heat transfer and pressure drop of $\mathrm{ZnO} /$ ethylene glycol-water nanofluids in transition flow." Applied Thermal Engineering 93 (2016): 537-548. https://doi.org/10.1016/i.applthermaleng.2015.09.020

[40] Nasrin, Rehena, Nasrudin Abd Rahim, Hussain Fayaz, and Md Hasanuzzaman. "Water/MWCNT nanofluid based cooling system of PVT: Experimental and numerical research." Renewable Energy 121 (2018): 286-300. https://doi.org/10.1016/j.renene.2018.01.014

[41] Sarsam, Wail Sami, S. N. Kazi, and A. Badarudin. "A review of studies on using nanofluids in flat-plate solar collectors." Solar Energy 122 (2015): 1245-1265. https://doi.org/10.1016/j.solener.2015.10.032

[42] Bergman, T. L. "Effect of reduced specific heats of nanofluids on single phase, laminar internal forced convection." International Journal of heat and mass Transfer 52, no. 5-6 (2009): 1240-1244. https://doi.org/10.1016/i.ijheatmasstransfer.2008.08.019

[43] Wilk, Joanna, Robert Smusz, and Sebastian Grosicki. "Thermophysical properties of water based Cu nanofluid used in special type of coil heat exchanger." Applied Thermal Engineering 127 (2017): 933-943. https://doi.org/10.1016/i.applthermaleng.2017.08.078

[44] Pak, Bock Choon, and Young I. Cho. "Hydrodynamic and heat transfer study of dispersed fluids with submicron metallic oxide particles." Experimental Heat Transfer an International Journal 11, no. 2 (1998): 151-170. https://doi.org/10.1080/08916159808946559

[45] Kretzschmar, Hans-Joachim, and Wolfgang Wagner. International Steam Tables: Properties of Water and Steam Based on the Industrial Formulation IAPWS-IF97. Springer, 2019. https://doi.org/10.1007/978-3-662-53219-5

[46] Philip, John, and Porumpathparambil Da Shima. "Thermal properties of nanofluids." Advances in colloid and interface science 183 (2012): 30-45. https://doi.org/10.1016/j.cis.2012.08.001

[47] Hashim, Walaa Mousa, Ali Talib Shomran, Hasan Ali Jurmut, Tayser Sumer Gaaz, Abdul Amir H. Kadhum, and Ahmed A. Al-Amiery. "Case study on solar water heating for flat plate collector." Case studies in thermal engineering 12 (2018): 666-671. https://doi.org/10.1016/j.csite.2018.09.002

[48] Badiei, Z., M. Eslami, and K. Jafarpur. "Performance improvements in solar flat plate collectors by integrating with phase change materials and fins: A CFD modeling." Energy $192 \quad$ (2020): 116719. https://doi.org/10.1016/j.energy.2019.116719

[49] Kadhim Sharaf, Hussein, Nawal Aswan Abdul Jalil, and Sadeq Salman. "A simulation on the effect of ultrasonic vibration on ultrasonic assisted soldering of $\mathrm{Cu} / \mathrm{SAC} 305 / \mathrm{Cu}$ joint." Journal of Advanced Research in Applied Mechanics 36, no. 1 (2017): 1-9.

[50] Salbi, Noorsabrina M., Norhayati Muhammad, and Norazlin Abdullah. "The Effect of Maltodextrin and Acacia Gum on Encapsulation of Fig Powder Physicochemical Properties." Journal of Advanced Research in Applied Sciences and Engineering Technology 22, no. 1 (2021): 8-15. https://doi.org/10.37934/araset.22.1.815 